(C) В.М. Шимон, Ю.Ю. Меклеш, 2019

УДК 616.71-001-089.84-74:615.464

\title{
Хірургічне лікування переломів довгих кісток із використанням керамічних імплантів (огляд літератури)
}

\author{
В.М. Шимон, Ю.Ю. Меклеш
}

Kaftravm@ rambler.ru

Ужгородський національний університет, медичний факультет, кафедра загальної хірургії

із курсами травматології, оперативної хірургї̈ та судової медицини, Ужгород

\section{Реферат}

У статті розглянуто історичний аспект та сучасний стан проблеми розробки та використання імплантів для заміщення дефектів кісткової тканини. Істотний сегмент сучасного ринку науковоємних технологій становить розробка і виробництво біоматеріалів. Створення «штучної кістки» є першочерговим завданням медичного матеріалознавства, яке може бути вирішене вченими шляхом розробки біоактивних склоподібних та керамічних матеріалів з високою резорбційною здатністю, не токсичністю та біосумісністю. Характер регенеративних процесів у значній мірі визначається властивостями матеріалів, які використовуються для заповнення дефектів кістки. Сучасний рівень медицини важко уявити без біологічних імплантів, за допомогою яких виконуються реконструктивні хірургічні втручання в травматології-ортопедії, щелепно-лицевій хірургії.

Найбільш широкомасштабні дослідження виконані в галузі отримання та клінічного застосування матеріалів на основі гідроксиапатиту. Для підвищення здатності до тимчасової механічної функції необхідні більш щільні кісткові замінники. Серед представників кераміки перевагу у міцності має гідророксилапатит (ГА). Для підвищення остеоінтегративних властивостей, здатності до переносу та поступового вивільнення стимуляторів остеогенезу потрібен високопористий кістковий замінник. У цьому випадку переваги має біфосфатна кераміка (БФ) на основі ГА, здатність якої до біодеградації вище, ніж ГА, але показники міцності недостатні для використання у навантажених ділянках скелета. Незважаючи на існування значної різноманітності зразків ГА чи кераміки, що відрізняються за складом, пористістю та, відповідно, міцністю, до теперішнього часу не існує диференційованого підходу до вибору кісткового замінника в залежності від характеру та локалізації порожнинного кісткового дефекту, його розмірів та умов навантаження. На основі виконаного аналітичного аналізу літературних даних щодо проблеми використання імплантаційних матеріалів для пластики кісткових порожнин в ортопедії та травматології можна зробити висновки щодо актуальності та значущості вибраного напрямку наукового дослідження та окреслити деякі аспекти розвитку цієї проблеми, а також визначити питання, котрі потребують подальшого вирішення.

Ключові слова: кісткова тканина, дефект, гідроксилапатитна кераміка, біфосфатна кераміка, імплантат.

Surgical treatment of long bone fractures using ceramic implants (literature review)

V.M. Shymon, Yu. Meklesh

Uzhhorod National University, Higher Educational Institution, Faculty of Medicine, Department of General Surgery (with courses in traumatology, surgery and forensic medicine), Uzhhorod

\section{Abstract}

The article deals with the historical aspect and current state of the problem of the development and use of implants for bone defect replacement. An important segment of the modern market for science-intensive technologies is the development and production of biomaterials. Creating an "artificial bone" is a primary task of medical materials science, which can be solved by scientists by developing bioactive vitreous and ceramic materials with high resorption capacity, non-toxicity and biocompatibility. The nature of regenerative processes is largely determined by the properties of the materials used to fill bone defects. It is difficult to imagine the current level of medicine without biological implants, by means of which reconstructive surgical interventions in traumatology-orthopedics, maxillofacial surgery are performed.

The most extensive studies have been performed in the field of production and clinical application of hydroxyapatite-based materials. More dense bone substitutes are needed to increase the ability to perform temporary mechanical function. Among the representatives of ceramics, the advantage in strength is hydroxylapatite (HA). A highly porous bone substitute is required to enhance osteointegrative properties, the ability to tolerate, and the gradual release of osteogenesis stimulators. In this case, bisphosphate ceramics (BF) is based on HA, whose biodegradability is higher than HA, but strength indicators are not sufficient for use in loaded areas of the skeleton. Despite the existence of a significant variety of samples of HA or ceramics, differing in composition and, accordingly, durability, to date, there is no differentiated approach to the choice of bone substitute, depending on the nature and localization of the cavity bone defect, its size and loading conditions. Based on the analytical analysis of the literature on the problem of the use of implant materials for bone plastic cavities in orthopedics and traumatology, we can conclude on the relevance and importance of the chosen direction of scientific research and outline some aspects of the development of this problem, as well as identify issues that need further resolution.

Key words: bone tissue, defect, hydroxylapatite ceramics, bisphosphate ceramics, implant. 
Сучасне покоління людей живе у вік науково-технічного, соціального прогресу, які формують напрямки розвитку людської цивілізації.

Для людства одним із засобів успішного функціонування соціально-економічних систем та інститутів культури $є$ розвиток медицини. Істотний сегмент сучасного ринку науковоємних технологій становить розробка і виробництво біоматеріалів, таким чином, дослідження в галузі матеріалів медичного призначення є одним із актуальних напрямків молекулярної біології, біофізики, хімії та медицини. Йдуть довгі пошуки створення «штучної кістки», що є першочерговим завданням медичного матеріалознавства, що може бути вирішене вченими шляхом розробки біоактивних склоподібних та керамічних матеріалів 3 високою резорбційною здатністю, не токсичністю та біосумісністю.

Проблеми відновлення анатомічної активності і функції кістки до сьогодення залишаються актуальними і їх пошуки тривають $[1,2,3,4]$.

Кісткові дефекти, які утворилися після травми, хірургічних втручань, пухлин кісток, потребують використання повноцінних пластичних матеріалів. За останні десятиліття особливо практична медицина має дефіцит біопластичного матеріалу - це зумовлено як ростом кількості і важкості травм, так і неблагоприємними екологічними факторами, а також широким впровадженням у практику нових технологій, ускладненням техніки об'єму, реконструктивно-відновлювальних втручань, яка виконується на кістковій системі, при цьому тривалість лікування хворих і їх непрацездатність приблизно 8-10 місяців, а інколи до 2-3 років, а в 8$10 \%$ закінчується стійкою інвалідністю, це веде за собою великі економічні затрати. Дана проблема має не тільки важливу медичну, але i соціальну значимість, тому вчені нашої країни і зарубіжних держав направлені на пошуки $[5,6,7]$.

Вишукування можливостей управління репаративними процесами вивчення закономірностей новоутвореної кісткової тканини при пластиці дефектів кістково-пластичними матеріалами, скорочення термінів перебудови, за рахунок адекватного матеріалу і використання матеріалів iз заданим набором якості $\epsilon$ актуальним матеріалом як анатомії, так і для травматології та ортопедії $[8,9]$.

Характер регенеративних процесів у значній мірі визначається якістю матеріалів, які використовуються для заміщення дефектів кістки. Сучасний рівень медицини важко уявити без біологічних матеріалів, із допомогою яких використовуються реконструктивні хірургічні втручання в травматології та ортопедії, хірургії, а також велика частка в онкологічній практиці $[10,11,12,13]$.
Пошкодження і захворювання кісткової тканини займають одне із перших місць серед причин інвалідності та тимчасової непрацездатності. Для відновлення функції кісткової тканини необхідно використовувати імплантати 3 різних матеріалів, тому що в ідеальному випадку замінник повинен бути біологічно сумісний із тканинами, тобто не мати токсичної дії, не викликати небезпечну реакцію з організмом і бути біологічно активним, тобто вступати у взаємодію 3 тканинами в ділянці імплантації, а в разі імплантації в кістку мати остеоінтегративні якості. За даними, лише в США хірургічного лікування $з$ використанням біоматеріалів потребували більш ніж 2 млн кісткових дефектів, що обумовлює актуальність розробки та дослідження матеріалів перспективних для сучасної травматології та ортопедії.

У класифікації матеріалів визначають трансплантат та імплантат. Тлумачення термінів взято із Великого Оксфордського Медичного Тлумачного Словника (Oxford Concise Medical Dictionary).

Імплантат (Implant, graft): 1) лікарський засіб, протез чи джерело радіоактивних речовин, які вводяться в тіло.

Трансплантат (transplant, graft) - будь-який орган, тканина чи частина тіла, які використовуються для пересадки з метою заміщення пошкодженої частини тіла.

Трансплантація (від латинського trans - пере i plantation - посадка) - пересадка органа або тканини.

Велика путанина виникає при перекладі англійського слова «graft», що означає як трансплантат, так і імлантат. Вибір терміна повністю залежить від змісту, хоча саме імплантат має найближче значення. Терміном «трансплантат» може називатися тільки жива тканина, клітковий елемент, який зберіг здатність до активного росту та поділу.

Кісткові трансплантати в клінічній практиці використовуються для заміщення і відновлення структурної цілістності тканини і підвищення остеогенного потенціалу кісткової тканини. В останній рік значно збільшилося використання кісткових трансплантатів для реконструкції скелета, у зв'язку 3 успіхами в розумінні біологічних процесів при трансплантації кістки $[5,14]$.

«Золотим стандартом» для заміщення кісткових дефектів вважається аутотрансплантат. Із біологічної та клінічної точки зору цей матеріал $\epsilon$ ідеальним для кісткової пластики. Однак слід зазначити, що можливості отримання їх в достатній кількості для заміщення великих кісткових дефектів обмежена. Крім того, взяття аутотрансплантата пов'язано 3 серйозними ускладненнями: хворобливість донорського ділянки в $49 \%$, виражений хронічний біль на рівні забору 
трансплантата в 29\%, косметичний дефект у $40 \%$ випадків, $10 \%$ гематоми, від 1,2 до $1,7 \%$ інфекція, переломи клубової кістки, і рідко пошкодження нервів або артерій. Із цих міркувань триває пошук замінників, які здатні скласти альтернативу аутотрансплантатам [15].

Ідеальний кістковопластичний матеріал повинен виконувати не тільки замісну функцію, а й поступово інтегруватися в навколишне кістка, підтримувати фізіологічний рівень остеобластичної і остеокластичної активності, сприяючи формуванню і ремоделлювання кісткової тканини. Трансплантат може виконувати функції остеоіндуктивной матриці, яка, будучи каркасом або гратами, підтримуватиме вростання нової кістки з боку ложа: алогенна губчаста або кортикальна кістка, трансплантати замінники. Зв'язок біоматеріалів 3 навколишніми тканинами, характер остеогенеза і стійкість імплантату в кістковому ложі залежить від фізико-хімічних властивостей матеріалу, що визначають його біоінертність та біоактивність. Біоінертністьздатність матеріалу протягом тривалого часу зберігати сталість свого складу і структури. До біоінертних матеріалів відносяться метали, їх сплави, полімери, кераміка, вуглець. Навколо біоінертних матеріалів, особливо з гладкою поверхнею, утворюється фіброзна капсула, за допомогою якої організм захищається від стороннього тіла (аутогенна, алогенна, губчаста або кортикальна кістка, демінералізований кістковий матрикс, трансплантати-замінники на основі кальцію фосфату, аутологічний кістковий мозок) $[16,17,18]$.

Трансплантати повинні заповнювати кістковий дефект на певний період часу, не викликати реакції імунологічного відторгнення, володіти здатністю до біодеградації з поступовим заміщенням кісткою. Крім цих класичних вимог, висловлюється побажання про надання трансплантатам біологічної активності.

Існуючі матеріали, які в тій чи іншій мірі відповідають вказанним вимогам, діляться на чотири групи:

- біоорганічні: ембріональна кісткова тканина, демінералізований кістковий матрикс, колаген, фібриновий клей, фібрин-колагенова паста;

- керамічні: 3-трікальційфосфатна кераміка, корал, паризький пластир і ін.;

- синтетичні полімери: полімолочна кислота, поліактид-полігліколід сополімер, поліангідрид і поліортоестер;

- композиційні: поєднують властивості різних груп, представлених вище.

Ці групи матеріалів по дії на навколишні тканини можна розділити на токсичні матеріали - призводять до загибелі тканин, нетоксичні біодеградіруючі матеріали - заміщуються кістковою або фіброзної тканиною, нетоксичні біоінертні матеріали - викликають утворення фіброзної капсули на їх поверхні, нетоксичні біологічно активні матеріали - утворюють прямий зв'язок із кістковою тканиною.

Таким чином, ідеальний імплантат повинен мати такі характеристики: висока остеогенна потенція і відсутність антигенної активності, простотою отримання і постійною доступністю, зручною для клінічного застосування геометричною формою і здатністю до біодеградації, не перешкоджати косетеоутворенню [19,20].

Використання для пластики дефектів кістки штучних матеріалів, ідентичних до мінеральної складової кісткової речовини, привертає увагу дослідників. Особливе місце серед біоактивних керамік займають трикальційфосфат і гідроксиапатит, які володіють не тільки високою спорідненістю 3 кістковою тканиною, але і здатністю до біодеградації. Препарати синтетичного гідроксиапатиту для медичного використання відомі $з$ кінця 60-х років, а дослідження в сфері технологій і синтезу не припиняються до тепер [21].

Гідроксиапатит (ГАП) - повний хімічний і кристалохімічний аналог мінеральних речовин ссавців, що зумовлює його унікальні біологічні властивості: імунну сумісність та біоактивність - здатність стимулювати остеогенез, зростатися 3 кісткою, слугувати будівельним матеріалом для синтезу кістки і входити в склад кісткової тканини, що заміщуює імплантат із ГАП.

Гідроксиапатит - біологічно сумісна мінеральна речовина, склад його в середньому зображається як $\mathrm{Ca}_{10}\left(\mathrm{PO}_{4}\right)_{6}(\mathrm{OH})_{2}$.

Матеріали на основі гідроксиапатита умовно можна поділити на три основні типи, залежно від умов отримання:

1. Невідпалений (резорбуючий) гідроксиапатит, який поділяється на дрібнодисперсні порошки, наприклад «Остим», і порошки резорбуючого гідроксиапатита, наприклад ГА-100.

2. Високотемпературна кераміка (нерезорбуюча), в свою чергу включає в себе порошки («Гідроксиапол»), грануляти і блокові кераміки.

3. Дрібнодисперсний гідроксиапатит, який отримують при включенні кріогенного етапу в процес виготовлення.

Відмінність цих типів матеріалів полягає в тому, що вони отримуються в різних умовах. Резорбуючий гідроксиапатит синтезується в рідкофазній реакції при кімнатній температурі, характеризується низькою кристалічністю, високою здатністю до сорбції, відносно високою резорбцією в біологічному середовищі. Нерезорбуючий гідроксиапатит отримують після нагрівання при $800-1000^{\circ} \mathrm{C}$, внаслідок чого відбувається фазовий перехід у конденсаційнокристалічну форму, хімічно стабільну, практично нерозчинну у воді. Дрібнодисперсний гідроксиапатит, який отримують при включенні кріо- 
генного етапу в процес виготовлення, висококристалічний і має низьку розчинність у воді $[22,23]$.

Більш стабільний високотемпературний гідроксиапатит володіє меншою остеопротекторною здатністю, слугує основою, на якій відбувається відтворення власних кісткових структур. Його рекомендують використовувати при закритті невеликих кісткових дефектів. Резорбуючий гідроксиапатит володіє більшим остеопродуктивним ефектом, який може доповнюватися остеоіндуктивною дією кісткового морфогенетичного білка, який сорбується частинками гідроксиапатиту.

На процес біодеградації кераміки також впливають: структура пористості (величина пор та їх архітектоніка), топографія і площа поверхні, фактори мікрооточення - $\mathrm{pH}$ середовища, клітковий склад, структура матрикса, який оточує кераміку кісткової тканини. Встановлено що площа поверхні однакових за розміром щільного і пористого зразків відрізняються в десятки разів. При цьому деградація щільних зразків ГАП в основному пов'язана тільки 3 їх розчинністю [24,25]. На міжнародному з'їзі імплантологів у 1997 році гідроксиапатит названий «кращим медичним матеріалом всіх часів». Практично, без цього матеріалу вже не можна уявити собі сучасну ортопедію, стоматологію, щелепно-лицеву хірургію.

Кераміка природного походження, яка містить близько 98\% карбонату кальцію, як замінника, була успішно застосована в спінальній хірургії. Також досліджена фосфорнокальцієва кераміка, головним чином штучна, i фосфорно-кальцієві цементи. Фосфорнокальцієві цементи не викликають загальної або місцевої токсичності, не зважаючи на певну кислотність в ділянці імплантації. Цементи поступово резорбуются і прогресивно замінюються кісткою, вони зникають, не сповільнюючи звичайне утворення кісткової мозолі [ 26,27].

Остеоінтеграція кераміки в людській кістці, без волокнистої прослойки між кісткою реципієнта і замісника, а також між замісником i відновленою кісткою, доведена на основі переконливих гістологічних результатів. Однак кераміка не має остеоіндуктівного ефекту в людини, всупереч доведеному у собак.

Із 1996 року кераміка стала використовуватися у випадках значного дефекту кісткової субстанції в травматології, отримані успішні результати. Відсутність ускладнень, характерне для цих замісників, пояснює, що показання швидко розширилися на псевдоартрози і доброякісні пухлини [28].

Oonishi Н. (1997) відкрив шлях використання чистого гідроксиапатиту в гранулах, щоб заповнити ним вертлюгові впадини.

Двофазна кальцій-фосфатна кераміка, сформована з суміші гідроксиапатиту і 5 -трикальцій- фосфату, вважається більш біоактивною і більш ефективною ніж ГА для відновлення кісткових дефектів [29,30,31].

Однак крім очевидних плюсів гідроксіапатитна кераміка має і певні недоліки. Вона не має прямої остеоіндуктивної дії, однак для керамік характерна вторинна індукція, а саме - сорбція активних факторів росту на поверхні, що обумовлює вторинну остеогенну активність.

Використання колагену як сполучної ланки може викликати автоімунні реакції, можливий прояв імунної реакції відторгнення трансплантата.

Кількість лікарської речовини (антисептиків) в гідроксіапатитній кераміці становить до $30 \%$ від маси, що перевищує мінімально необхідну кількість у декілька разів і навряд чи виправдано.

Кістка - це тканина, яка складається із органічного компонента що забезпечує можливість його розвитку і адаптації до змін в навколишньому середовищі неорганічного матеріалу, рідина якого визначається 3 його структурою і неправильним складом, який є в основному кальцієм, фтором у вигляді багатофазних кальційфосфатних з'єднань, які мають магній, натрій і інші мікроелементи ( $\mathrm{Sr}, \mathrm{Sn}, \mathrm{CO}, \mathrm{Fe}, \mathrm{Cu}$ і більше). Вони знаходяться в динамічній рівновазі внаслідок сумісного перебігу процесів утворення i peзорбції кісткової тканини.

Традиційно в медичній практиці, в основному, використовують матеріали з високотемпературних ортофосфатів, що пов'язано з процесами спікання кераміки. Найбільший інтерес для застосування представляють ГА, В-ТКФ і біфазні матеріали на основі цих сполук [32,33].

Монокальцієвий фосфат не вважають біосумісним через кислотні реакції. Обидві модифікації а і $\beta$ - ТКФ біосумісні і виявляють біорезорбуючі властивості більшою мірою, ніж ГА. Останній $\epsilon$ найбільш стійким до розчинення (при рН> 4,7) з ортофосфатів, він кристалізується при нагріванні ОДА стехіометричного складу і переходить в оксиапатит у результаті часткового розкладання при температурах вище $900^{\circ} \mathrm{C}$ в середовищі, що не містить водяної пари. При високих температурах, вище $1300^{\circ} \mathrm{C}$, ГА розкладається на а-ТКФ i тетракальційфосфат (ТеКФ). Тетракальційфосфат синтезують твердофазною взаємодією ДКФ 3 карбонатом кальцію, він характеризується високою розчинністю у водних розчинах при $\mathrm{pH}<5$. Його часто використовують як компонент кісткових цементів у поєднанні з більш кислими фосфатами.

ТКФ існує в двох кристалічних модифікаціях: високотемпературній - a-ТКФ i низькотемпературній - $\beta$-ТКФ. Рентгенівська щільність $\beta$-ТКФ становить 3,067 г/ $\mathrm{cm}^{3}$, температура розкладання $1380^{\circ} \mathrm{C}$, для а-ТКФ ці параметри мають значення 2,18 г/см3 і $1720^{\circ} \mathrm{C}$, відповідно. Фазове перетворення $\beta$-ТКФ в а- 
ТКФ відбувається в температурному інтервалі $1200-1400^{\circ}$ C і супроводжується збільшенням обсягу матеріалу. Оскільки дане перетворення протікає повільно, то обидві форми ТКФ можна виявити при кімнатній температурі, причому аформа метастабільна [34,35].

Серед всіх існуючих біоактивних матеріалів на сьогоднішній день набули найбільшого поширення матеріали на основі кристалічних фосфатів кальцію (біокераміка). Пов'язано це насамперед iз тим, що сама мінеральна фаза кісткової тканини представлена фосфатами кальцію, і таким чином зазначені матеріали найбільш близькі за властивостями до природної кістки. Біокераміку отримують спіканням порошків фосфатів кальцію при різних температурах, що лежать в діапазоні $1000-1300^{\circ} \mathrm{C}$.

Існують три основні методи синтезу фосфатів кальцію: осадження 3 розчинів (мокрий метод), твердофазовий синтез (сухий метод) і гідротермальний синтез [3]. Залежно від методу синтезу може бути отриманий порошок необхідного фосфату кальцію 3 різною морфологією, питомою поверхнею, стехіометрією і ступенем кристалічності. На практиці переважає синтез фосфатів кальцію з водних розчинів (мокрий метод). Для даного способу характерно безліч несприятливих чинників, які не завжди дають можливість досягти хорошу відтворюваність, зберегти стехіометричне співвідношення Са / P в процесі синтезу, тобто отримати порошок із заданими хімічними і фізичними властивостями. Серед таких факторів найбільш критичними $\epsilon \mathrm{pH}$ розчину, температура реакції і тривалість процесу. Твердофазовий (сухий) синтез фосфатів є найбільш тривалим i енергоємним. Крім того, цим способом отримання порошків важко досягти гомогенності кінцевого продукту. Тому даний метод не знайшов широкого застосування в практичних цілях $[36,37,38]$.

Найбільш широкомасштабні дослідження виконані в галузі отримання та клінічного застосування матеріалів на основі гідроксиапатиту. Гідроксиапатитова кераміка добре зростається 3 живою кісткою, міцність зв'язку може досягати до 23 МПа. Дослідники ще 3 початку XX століття почали вивчати можливість використання цього матеріалу як потенційного замінника кістки, однак систематичне дослідження можливості його застосування в медицині було розпочато тільки в 70-х роках XX століття, перші результати отримані колективами дослідників під керівництвом Аокі i Ярчо. На сьогоднішній день широке медичне застосування вже знайшли матеріали на основі гідроксиапатиту: «Interpore 200» i «Interpore 500», що випускаються в блоках і гранулах. Склад матеріалу: 94\% ГА; 6\% а-ТКФ [39].

До недоліків гідроксіапатитової кераміки як імплантаційного матеріалу відноситься іiі низька резорбційна здатність, що визначає тривалі терміни зрощення 3 живою кістковою тканиною, а також сильна залежність хімічного складу від умов синтезу. Останнє призводить до суттєвої нестабільності медико-біологічних властивостей матеріалу.

Трикальційфосфат (ТКФ) [Ca3 (Р04) 2] існує в двох формах, які називаються $\mathrm{a}-\mathrm{i} \beta$ трикальційфосфат, а-форма має меншу стійкість

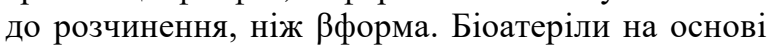
а-трикальцій фосфату відносяться до резорбуючих матеріалів. Ідеальний штучний імплантат, створений з а-ТКФ, повинен повністю розсмоктатися і замінитися новою кістковою тканиною, оскільки в цьому випадку проблеми міцності зв'язку та біосумісності не виникають взагалі. Складність полягає в тому, що поки імплантат не «розсмоктався» і не виросла нова кістка, будь-які навантаження протипоказані. А отже, пацієнт повинен провести в ліжку багато місяців і навіть роки, оскільки кістки (особливо великі) ростуть повільно [40,41,42].

Невдалим $є$ використання кальційфосфатной біокераміки для умов важких навантажень (кістки опорно-рухового апарату) через пї низьку міцність, особливо у вологих навколишніх середовищах. На сьогоднішній день сферою застосування матеріалів на основі спечених кальційфосфатних матеріалів $\epsilon$ невеликі ненавантажені імплантати, порошки і гранули. Однак проводиться безліч досліджень 3 метою отримати механічно більш надійну біоактивну кераміку, включаючи і матеріали на основі ГА.

Останнім часом увагу розробників і практикуючих хірургів залучають імплантаційні матеріали на основі силікатних і кальційфосфатних систем - біоскла і біометалів. Їх істотною перевагою $є$ можливість широкого варіювання інтенсивності взаємодії з живими тканинами організму - від повного розчинення в фізіологічному середовищі протягом короткого проміжку часу (біодеградація) до високої стійкості в цьому середовищі (біорезистентність). Такий широкий діапазон властивостей створює передумови для розробки біоактивних матеріалів різного призначення - від лікувальних препаратів, що інтенсифікують процеси остеогенезу в організмі, до кісткових імплантатів та ендопротезів тривалого терміну служби $[4,11]$.

Інформація про конфлікт інтересів. Автори декларують відсутність конфлікту інтересів.

Список використаної літератури

1. Баринов, С. М., \& Комлев, В. С. (2005). Биокерамика на основе фосфатов кальция. Наука. 205 с. 
2. Безсмертний, Ю. О. (2013). Структурно-функціональний стан кісткової тканини при порушеннях репаративного остеогенезу на фоні гіпергомоцистеїнемії. Український медичний альманах. (16. № 1). 126-128. 3. Бережной, Е. П. (2010). Гистологическое строение диафиза при имплантации в большеберцовые кости керамического гидроксилапатита и деминерализованного костного матрикса. Український морфологічний альманах, 8(3), 13-16.

4. Бруско, А. Т., \& Гайко, Г. В. (2014). Современные представления о стадиях репаративной регенерации костной ткани при переломах. Вісник ортопедії, травматології та протезування, (2), 5-8.

5. Берченко, Г. Н. (2008). Костные трансплантаты в травматологии и ортопедии. В сборнике работ:«Применение искусственного имплантата Коллапан в травматологии и ортопедии». М. 3-8.

6. Климовицкий, В. Г., Пастернак, В. Н., Оксимец, В. М., Верещагин, С. И., Дмитренко, А. А., \& Пастернак, Д. В. (2007). Влияние этиологического фактора травмы на течение репаративного остеогенеза. Часть 1. Сращение диафизарных переломов голени при непрямом механизме травмы. Травма, 8(1), 7-11.

7. Hasan, M. S., Ahmed, I., Parsons, A. J., Rudd, C. D., Walker, G. S., \& Scotchford, C. A. (2013). Invest igating the use of coupling agents to improve the interfacial properties between a resorbable phosphate glass and polylactic acid matrix. Journal of biomaterials applications, 28(3), 354-366.

8. Климовицкий, В. Г., Оксимец, В. М., Черныш, В. Ю., Попандопуло, А. Г., \& Оберемко, А. В. (2008). Влияние механизма травмы на состояние периостальных источников остеорепарации. Травма, 9(4), 390-395.

9. Klymovytskyi, V. H., Sheviakin, D. V., Lobanov, H. V., Zarytskyi, A. B., \& Zoloto, M. S. (2016). Anatomical and Surgical Features of Blood Supply to the Femoral Shaft. TRAUMA, 17(1), 24-27.

10. Гайко, Г. В., \& Бруско, А. Т. (2013). Теоретические аспекты физиологической и репаративной регенерации костей с позиций системных представлений. Журнал Національної академії медичних наук України, (19,№ 4), 471-481.

11. Дедух, Н. В., \& Побел, Е. А. (2013). Регенерация кости: основные тенденции развития проблемы. Журнал «Боль. Суставы. Позвоночник, $1,09$.

12. Eliaz, N., \& Metoki, N. (2017). Calcium phosphate bioceramics: a review of their history, structure, properties, coating technologies and biomedical applications. Materials, 10(4), 334.

13. Кирилова, И. А. (2011). Костная ткань как основа остеопластических материалов для восстано вления костной структуры. Хирургия позвоночника, (1), 68-74.

14. Корж, Н. А., Радченко, В. А., Кладченко, Л. А., \& Малышкина, С. В. (2003). Имплантационные материалы и остеогенез. Роль индукции и кондукции в остеогенезе. Ортопед., травматол. и протезир, (2), $150-157$.

15. Омельяненко, Н. П., Малахов, О. А., \& Сухих, Г. Т. (2000). Исследование влияния эмбриональной костной ткани на репаративную регенерацию кости. Бюл. эксперимент. биологии и медицины, $10,469-74$.

16. Корж, М. О., \& Безсмертний, Ю. О. (2013). Особливості лікування хворих з несправжніми суглобами довгих кісток за умов гіпергомоцистеїнемії та асоційованих станів. Ортопедия, трав матология и протезирование, (2), 5-14.

17. Корж, Н. А., Кладченко, Л. А., \& Малышкина, С. В. (2008). Имплантационные материалы и остеогенез. Роль оптимизации и стимуляции в реконструкции кости. Ортопедия, травматология и протезирование, (4), 5-14.

18. Корж, Н. А., Дедух, Н. В., \& Никольченко, О. А. (2006). Репаративная регенерация кости: современный взгляд на проблему. Стадии регенерации. Ортопедия, травматология и протезирование, 1, 77-84.

19. Мироманов, А. М., Гусев, К. А., \& Усков, С. А. (2013). Значение маркеров резорбции костной ткани в прогнозе развития замедленной консолидации переломов длинных костей конечностей. Acta Biomedica Scientifica, (2-1 (90)).

20. Попсуйшапка, А. К., Ужигова, О. Е., \& Литвишко, В. А. (2013). Частота несращения и замедленного сращения отломков при изолированных диафизарных переломах длинных костей конечностей. Ортопедия, травматология и протезирование, (1), 39-43.

21. Резник, Л. Б., Рожков, К. Ю., Ерофеев, С. А., Дзюба, Г. Г., \& Котов, Д. В. (2015). Применение физических факторов для оптимизации костной регенерации (обзор литературы). Гений ортопедии, (1), 89-95.

22. Dorozhkin S.V. Calcium orthophosphates. J.Mater.Sci.2007;42: 1061-95.

23. Dorozhkin S.V. Calcium orthophosphate-based bioceramics. Materials 2013; 6:3840-942.

24. Zyman, Z. Z., Tkachenko, M. V., \& Polevodin, D. V. (2008). Preparation and characterization of biph asic calcium phosphate ceramics of desired composition. Journal of Materials Science: Materials in Medicine, 19(8), 2819-2825.

25. Salinas, A. J., \& Vallet-Regí, M. (2013). Bioactive ceramics: from bone grafts to tissue engineering. RSC Advances, 3(28), 11116-11131.

48 Науковий вісник Ужгородського університету, серія «Медицина», випуск 2 (60), 2019 р. 
26. Yasukawa, A., Gotoh, K., Tanaka, H., \& Kandori, K. (2012). Preparation and structure of calcium hydroxyapatite substituted with light rare earth ions. Colloids and Surfaces A: Physicochemical and Engineering Aspects, 393, 53-59.

27. Mestres, G., Le Van, C., \& Ginebra, M. P. (2012). Silicon-stabilized $\alpha$-tricalcium phosphate and its use in a calcium phosphate cement: characterization and cell response. Acta biomaterialia, 8(3), 1169-1179.

28. Гумінський, Ю. Й., Кореньков, О. В., \& Кореньков, А. В. (2009). Сучасні аспекти екоморфології репаративного остеогенезу, (1), 17-23.

29. Dorozhkin, S. (2013). Self-setting calcium orthophosphate formulations. Journal of functional biomaterials, 4(4), 209-311.

30. Wang, M. C., Shih, W. J., Hung, I. M., Chen, H. T., Hon, M. H., \& Huang, H. H. (2015). Characterization of calcium phosphate apatite with variable $\mathrm{Ca} / \mathrm{P}$ ratios sintered at low temperature. Ceramics International, 41(1), 1223-1233.

31. Филиппенко, В.А., Дедух, Н.В., Зыман, 3.3., Малышкина, С.В., \& Мезенцев В.А. (2004). Клинико-экспериментальные аспекты использования бифазной кальцийфосфатной керамики для пластики костных полостей. Проблеми остеологии, 7(3-4), 53-59.

32. Petrakova, N. V., Lysenkov, A. S., Ashmarin, A. A., Egorov, A. A., Fedotov, A. Y., Shvorneva, L. I.,... \& Barinov, S. M. (2013). Effect of hot pressing temperature on the microstructure and strength of hydrox yapatite ceramic. Inorganic Materials: Applied Research, 4(4), 362-367.

33. Tomoaia, G., Mocanu, A., Vida-Simiti, I., Jumate, N., Bobos, L. D., Soritau, O., \& Tomoaia-Cotisel, M. (2014). Silicon effect on the composition and structure of nanocalcium phosphates: in vitro biocompatibility to human osteoblasts. Materials Science and Engineering: C, 37, 37-47.

34. Habraken, W., Habibovic, P., Epple, M., \& Bohner, M. (2016). Calcium phosphates in biomedical applications: materials for the future?. Materials Today, 19(2), 69-87.

35. Zanotto, A., Saladino, M. L., Martino, D. C., \& Caponetti, E. (2012). Influence of temperature on calcium hydroxyapatite nanopowders. Advances in Nanoparticles, 1(3), 21-28.

36. Wang, C. G., Liao, J. W., Gou, B. D., Huang, J., Tang, R. K., Tao, J. H., .. \& Wang, K. (2009). Crystallization at multiple sites inside particles of amorphous calcium phosphate. Crystal Growth and Design, 9(6), 2620-2626.

37. Dorozhkin, S. (2015). Calcium orthophosphate-containing biocomposites and hybrid biomaterials for biomedical applications. Journal of functional biomaterials, 6(3), 708-832.

38. Boanini, E., Gazzano, M., \& Bigi, A. (2010). Ionic substitutions in calcium phosphates synthesized at low temperature. Acta biomaterialia, 6(6), 1882-1894.

39. Duan, R., Barbieri, D., Luo, X., Weng, J., Bao, C., De Bruijn, J. D., \& Yuan, H. (2018). Variation of the bone forming ability with the physicochemical properties of calcium phosphate bone substitutes. Biomaterials science, 6(1), 136-145.

40. Peters, F., \& Reif, D. (2004). Functional materials for bone regeneration from beta-tricalcium phosphate. Materialwissenschaft und Werkstofftechnik: Entwicklung, Fertigung, Prüfung, Eigenschaften und Anwendungen technischer Werkstoffe, 35(4), 203-207.

41. Tanaka, T., Komaki, H., Chazono, M., Kitasato, S., Kakuta, A., Akiyama, S., \& Marumo, K. (2017). Basic research and clinical application of beta-tricalcium phosphate ( $\beta$-TCP). Morphologie, 101(334), 164172.

42. Davison, N. L., ten Harkel, B., Schoenmaker, T., Luo, X., Yuan, H., Everts, V.,... \& de Bruijn, J. D. (2014). Osteoclast resorption of beta-tricalcium phosphate controlled by surface architecture. Biomaterials, 35(26), 7441-7451.

Стаття надійшла до редакції: 10.10 .2019 р. 